\title{
オープンアクセスジャーナル出版の実践 と考察
}

\section{理工系分野における学術誌}

Practice and consideration for publication of open-access journals

Academic journals in science and technology

谷藤 幹子 $^{1}$

\section{TANIFUJI Mikiko ${ }^{1}$}

1 物質・材料研究機構科学情報室（干305-0047 茨城県つくば市千現1-2-1）Tel: 029-859-2041

1 Scientific Information Office, National Institute for Materials Science (1-2-1 Sengen Tsukuba-shi, Ibaraki 305-0047)

著者抄録

材料科学分野における英文学術論文誌Science and Technology of Advanced Materials (STAM) は今年第10巻を迎えた。材 料研究先進国として, 国際的知名度を持ちうる専門誌を日本に持とうという学者間の機運をきっかけに, 材料系学協 会の有志により2000年に創刊された。物質・材料研究機構 (NIMS) は日本で唯一の材料科学専門の研究所として, 研 究のみならず研究成果の発信と普及にも力を入れており, 中でも学術出版は中核的基盤整備の一つとして位置づけて いる。材料科学分野における顕著な研究成果や, 研究の進展全体を俯瞰するレビュ一論文を編集し, 世界の材料研究 コミュニティーで共有することが出版の目的である。そのためには研究所といえども質のよい編集, 安定した出版体 制を持つことが重要であり, 段階的な出版体制作り, 編集改革, 出版工程の見直しを経て, 投稿・閲覧を無料化する という新しい戦略のもと, 購読型から機関負担型オープンアクセスジャーナルヘ転換した。出版量よりも材料研究者 必読論文を収録するという質重視への転換でもある。オープンアクセスジャーナルとして成功例の一つとされる物理 分野の学術誌N ew Journal of Physics（英国物理学会出版局発行）を参考例として, STAM誌の創成期から成熟期へ向けた 展望を俯瞰する。

キーワード

理工系, 学術誌, 研究者コミュニティー, 機関支援型オープンアクセスジャーナル, 著者負担型オープンアクセスジャー ナル, Science and Technology of Advanced Materials, New Journal of Physics, 英国物理学会出版局

1. はじめに

材料科学分野における英文学術論文誌Science and
Technology of Advanced Materials (STAM) は今年第 10巻を迎えた。材料研究先進国として, 国際的知 名度を持ちうる専門誌を日本に持とうという学者間 
の機運をきっかけに，材料系学協会の有志により 2000年に創刊された。日本で出版される学術誌の 多くは，学会が学会活動の一環として出版する場合 が多く, 会員がコミュニティー活動として査読編集 を支え, 出版という成果が学会へ収益あるいは社会 的知名度をもたらす。STAM誌は，緩やかな学会の 連合体という支援背景はあるものの, 実質の出版 経営は物質・材料研究機構 (NIMS) がすべてを担 うというユニークな立ち位置にある。NIMS1は日本 で唯一の材料科学専門の研究所として, 研究のみな らず研究の成果発信と普及にも力を入れており, 中 でも学術出版は中核的基盤整備の一つとして位置づ けられている。特に材料科学分野における顕著な進 展や, 研究発展の全体像を俯瞰したレビュ一論文を 編集し, 研究コミュニティーで共有することが出版 の目的である。そのためには研究所といえども質の よい編集，安定した出版体制を持つことが重要であ り，段階的な体制作りと編集改革を経て，2008年1 月，それまでの購読誌から機関負担型オープンアク セスジャーナルへ転換した。出版量よりも材料研究 者必読論文を収録するという質重視への転換でもあ る。投稿資格や費用負担なしに投稿ができ（free to submit)，認証や課金なく読むことができ(free to read), かつ著作者自身が著作権をもつ (author-friendly copyright）という研究者コミュニティーによる，研 究者主体の出版である。同じ精神でSTAMより前に 創刊され，オープンアクセスジャーナルとして成功 例の一つとされる物理分野の学術誌New Journal of Physicsを参考例として比較しながら，STAM誌の創 成期から成熟期へ向けた展望を俯瞰する。

\section{STAM一学術誌としての創成期}

一般に学術誌の創刊時は, 関係者の勢いもあって しばらくは特集企画や寄稿などによって分量が補わ れ，定期的な発行が続く。現在ではオンライン版の みの出版形態も普通の選択肢となったが，2000年
の創刊時はまず紙版ありきの時代で, 冊子として閉 じるに足るページ数の確保が必要であった。1999 年当時, 材料分野の英文学術誌は世界に300誌く らいは存在していただろう注1)。日本でも金属, 鉄 鋼, 材料, 工学, 物理, 応用物理分野などで学会か ら日・英学術誌は出版されていた。にもかかわらず 日本の材料研究を国際舞台で堂々と引用できる雑誌 媒体がないというのが, 当時の議論の発端であった と聞く。日本の学術誌に対して研究者が抱く不足感 は, 分野によって今日も同じかもしれない。理工系 の学術誌や雑誌がすでに世界に7,200誌以上存在し (2009年7月, エルセビア社発行の学術文献データ ベースSCOPUSの収録誌総数より), 今もなお新しい 学術誌が創刊される中, 日本の学術誌界を牽引する リーディングジャーナルとして世界を舞台に健闘し ている学術誌もある。こうした世界的飽和状態にあ る中で, 日本の学術誌の存在感が薄いという議論は, 古くも新しいテーマである注2)。

STAM誌の創刊当時, 14の材料系学協会が集まっ て日本材料工学連合 (Japan Federation of Materials) を形成して立ち上げ母体となったものの，実際には 連合会員の有志による活動に支えられていた。財政 基盤となるべき会費などの定常収入あるいは企業協 賛もない土壤での学術誌としても, STAM誌の成り 立ちは他に例をみない。創刊当時, 学術出版といえ ば世界一の規模とブランドカのあるエルゼビア社 (オランダ) がよいだろうということで, 発行責任 (英 語ではjournal ownershipと表現) と編集権は連合がも ち, 査読後論文の出版一切と独占的販売権を委託し た注3)。しかし, その後5年経っても収益は出ず, 学 術誌評価の一つの尺度であるインパクトファクター (トムソン・ロイター社) はつかず, 投稿層も広が りをみせず，世界にアピールするという当初目標の 達成は困難に思われた。学術誌として売れることが 第一義目的でないとはいえ, 5年経っても出版効果 の手ごたえがない場合は，編集の質や出版体制を見 直すべきである。まずは出版体制を強化することに 
なり, 物質・材料研究機構 (NIMS) がその役割を引 き受けることになった。当時のNIMS理事長の材料研 究分野における深い憂慮が英断につながつたと推測 する。2005年に出版経営母体をNIMS内に設置する にあたって具体的に行った出版体制の強化は以下の 通りである。

（1）材料研究の経験者を編集者として雇用。投稿論 文のプレスクリーニング，二重投稿チェックなど を行う。

（2）全体の支出を大きく変えない範囲で, 質の向上 に投資。具体的には大量の論文を出版するのでは なく，必読論文に厳選するあるいは招待論文を企 画する。

（3）掲載論文はすべて英文校正をする。

（4）出版後の論文配信と著者に代わるPRに重きを置 き，オンデマンド印刷などで主たる研究集会や学 会で配布する。

（5）国内外編集委員を招集する国際編集委員会を開 き, 編集委員間の問題意識や編集方針を共有する。 これらの改革や2007年の投稿のWeb化を経て, ま た同年にJCRに収録されたことも後押ししてか，投 稿が増え不採択率が約 $50 \%$ に上がる結果となった。

その後, 編集委員会で集中的に行った議論により 近年までに行った編集改革は以下の点である。

(1) 編集委員会の国際化(海外委員の招聘を含む 「ジャーナルの顔」を作る)

（2）編集方針，査読基準の見直し（出版したい論文 像を明確化する)

（3）特集企画依存から投稿・招待論文, 特にレビュー 論文中心へ転換

（4）編集工程のWeb化（投稿システム, 査読システ 厶, 制作管理工程のWebデータベース化)

（5）著者・査読者情報のデータベース化

（6）論文執筆の勧誘（author marketing）

（7）掲載論文の英語校閲

（8）オープンアクセスジャーナル化

これらを実現するには方法の選択と最適化，そし
て決まった予算額の中での投資比率の配分が重要で ある。学術誌はいわば長期的な投資であり, その投 資効果も定量的に見えにくいのが学術誌である。研 究者の「自分が常に目を通す5誌」に入らない限り は, 研究者の間で口コミで広がることも難しいほど に学術誌の数と種類は多い。一研究者がー日に論文 を読むのに割く時間は平均15分という調査もある注4)。 STAM編集委員会が目指すことは，編集委員会から 研究者のデスクトップに配信される“今月の必読論 文”の一つになることである。1，2か月に一つく らいの割合で, その研究領域を俯瞰する良質のレ ビュー論文が配信されたら, それは価值がある学術 誌（配信する媒体という意味のメディア）と言えよ う。そのような編集方針から，STAM誌は投稿論文 を多く募らない分, 掲載論文の質を上げることに投 資している。全体の支出配分は図1の通りである。

オープンアクセスジャーナル, すなわち売上を出 版費用に回す運営をしない以上, それまでの支出構 造の見直しも重要であるし, 公的機関であるから支 出の適正さも説明できる必要がある。国際競争入札 を経て, 上述の新しい編集・出版方針に最も適した 提案のあったイギリスの非営利出版団体英国物理学 会出版局 (IOP Publishing) が出版パートナーとして 選ばれた。上述の(4)〜 (6)については○Pの他理工系 学術誌での経験と技術力を生かし, 特に(8)を実現 するためのコストの見直しをすることによって機関 負担型のオープンアクセス化に至った。これについ

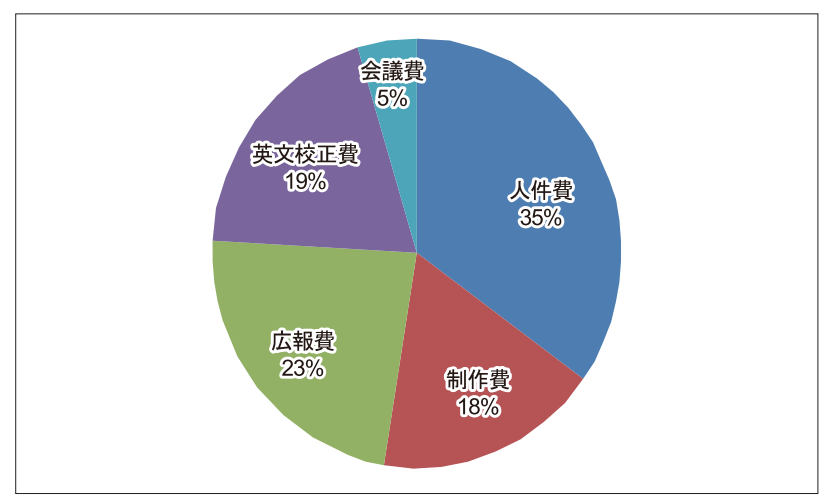

図1 出版費用の内訳 


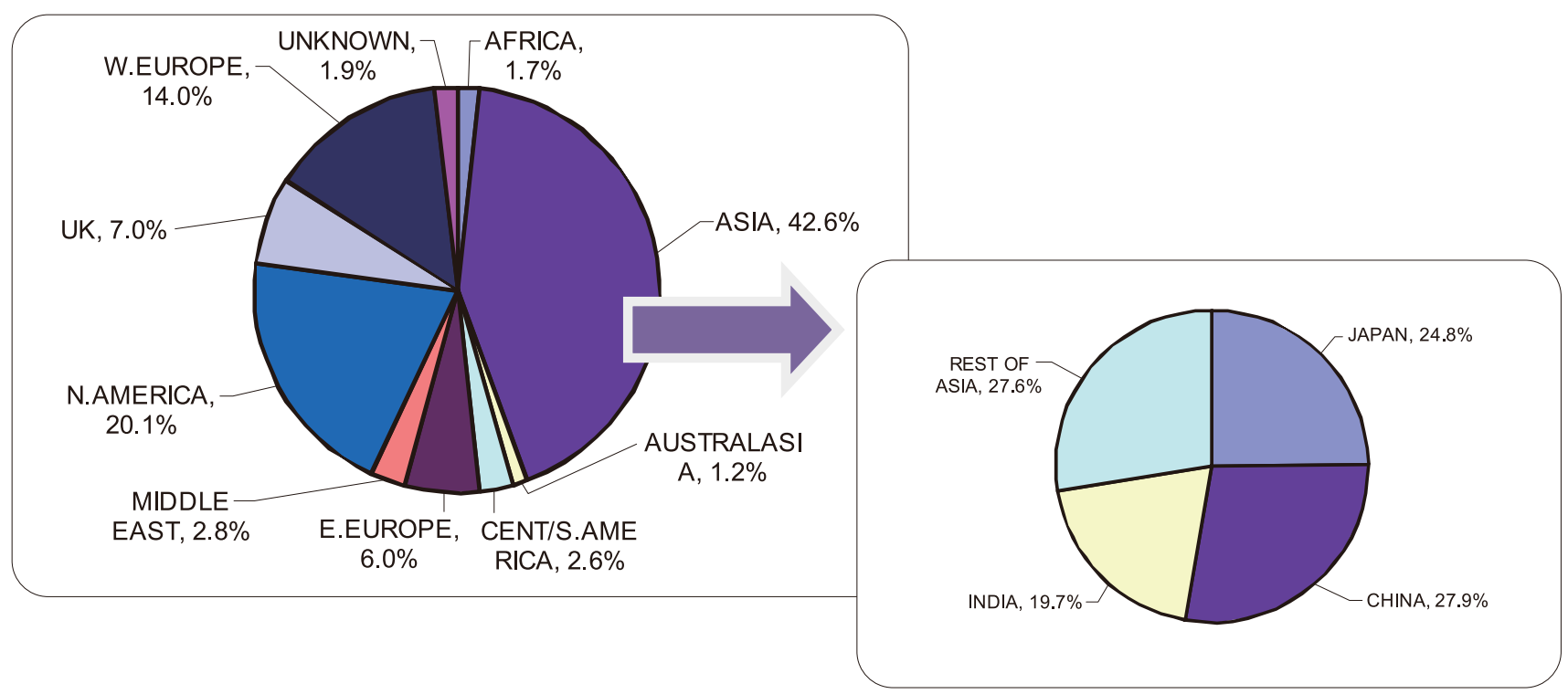

図2 STAM誌の現在の地域別アクセス内訳（左図）とアジア地域の内訳（右図）（2008年3月～2009年5月）

ては, 英国物理学会出版局から先行して発行され ていたオープンアクセスジャーナルNew Journal of Physics (NJP) の10年を参考亡して後述する。以上 の体制強化と編集改革を経て，STAM誌は図2に示す 読者分布に至った。

\section{3. 学術誌とオープンアクセスーこの 10 年}

\section{1 オープンアクセスジャーナル}

オープンアクセスジャーナルとは, 出版する費用 を読者が負担しない出版方法を意味する注5)。つま り購読機関を持たず，不特定多数の個人が無料で閲 覧する。街中には広告主が費用を負担する無料雑誌 やフリーペーパーがあり, 広告の域を超えた充実し た内容で人気がある。学術誌の場合, 研究論文を発 行する媒体であるから広告費で出版費をまかなう方 法注6) は歴史的にもあまり例がない。多くの場合, 読者が（あるいは読者が所属する機関が代わって） 購読料を支払い，それが出版費用に相当している。 商業出版社であればそこから利益を生みだす購読費 構造になっている。オープンアクセスジャーナルの 効用, 問題点, あるいは八イブリッド型ジャーナル (有料論文と著者負担による無料論文が混在する出
版方式）の実践と考察，調査報告は，学会5),6), 出 版社 ·図書館界7), 注7), 政府系団体9), 学者10) から 数多く出版されている。

STAM誌をオープンアクセス化する際に, 特に注 意した点は以下の2点である。

（1）年間出版量の目安の設定

出版費用は投稿された段階から発生する。不採択 論文著者に論文審査料を課金するという習慣がない ため，論文の不採択率が上昇すると採択論文あたり の負担費用が増えるという側面がある。編集方針と 深く相関するので，必読論文の判断基準を設ける必 要がある。

（2）到達目標の設定

出版とは，論文投稿，査読・編集，制作·校正， Web·紙出版, そしてデータベース会社による論文 書誌情報のインデクシングのためのデータ制作，才 ンライン版のアクセス解析と著者へのフィードバッ クサービスに至る全工程を指す。個々の工程でかか る時間と費用の合理化, あるいは先進的な機能性を さらに求める場合, オープソソース（ソースコード を公開しているソフトウエア)注8) から既製品まで 多様な選択肢の中から, (1)学術誌が対象としている 分野の文化, (2)読者が求める機能やサービス, (3)同 


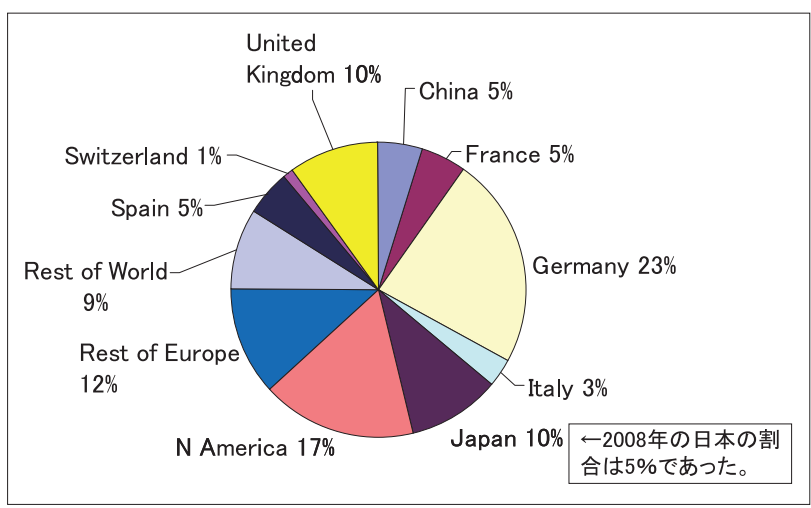

図3 NJP誌一2009年の論文代表著者 (corresponding author) の地域別分布

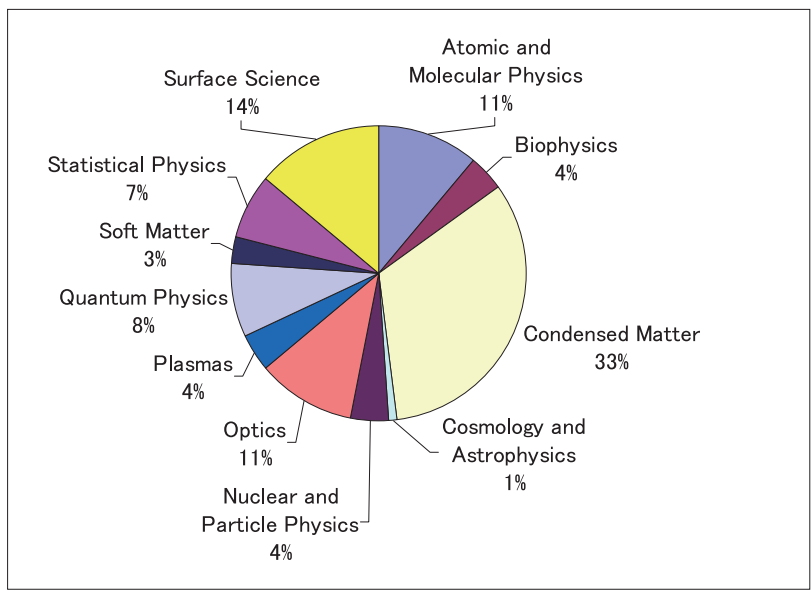

図4 N.JP誌一掲載論文の物理学細分野の分布

分野の他雑誌の取り組みなどを見極め，具体的な到 達目標を設定する必要がある注9)。出版工程のうち, 制作・Web出版や広報など部分的に委託する場合で も，対等な立場で目標の具現化に向けて共に取り組 むパートナー選びは大変に重要である。検討に際して はガイドライン “The Transfer Code of Practice”13), 注3) などを参考にした。

\section{2 オープンアクセスジャーナルとしての成果}

NJP誌は, 英国物理学会とドイツ物理学会が協力 して資金を提供し1997年に創刊された。物理学全 体を対象とした学術誌である。創刊趣旨は, 当時の 学術誌購読価格の急上昇に応え, 閲覧無料かつ永続 的に保存を保証する高品質な学術出版によって，物 理研究コミュニティーに資することであった。その 後5年の間に，インパクトファクターが上昇したこ

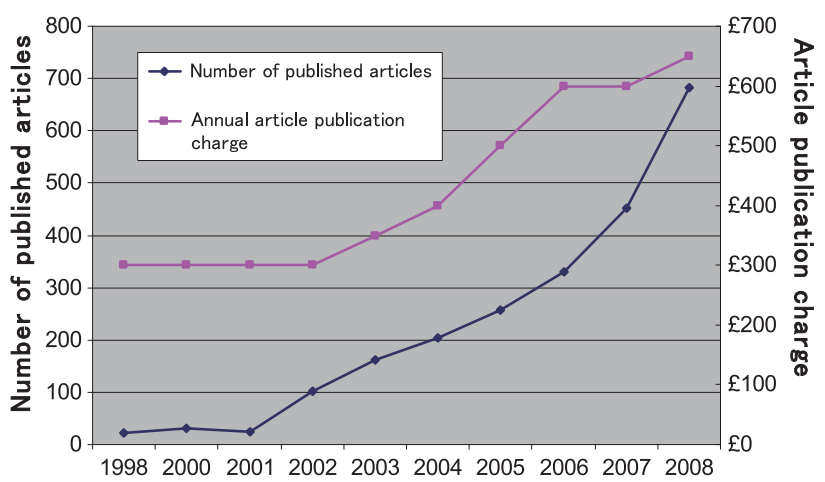

図5 NJP誌の創刊以来の出版論文数と掲載料の推移

とからrising starとして取り上げられ，オープンアクセス ジャーナルの成功例として各界から注目を集めた14)。 当時理工系分野ではパイオ二ア的に登場した著者負 担型オープンアクセスジャーナルであるが，ここに 至って日本の物理学者からも一定の支持を得ている ことが図3から，物理分野全体から一様に注目され ていることが図4から読み取ることができる。

学術誌として, また国際誌として, 対象とする著 者, 読者, 分野内でのバランスをうまくとり, それ がコミュニティーから支持されることは学術誌本来 の目的である。NJP誌の場合は, その出版費用を著 者が負担する著者負担型オープンアクセスジャーナ ルであるので, 前述した採択論文数とバランスがと れる出版費用の設定が欠かせない。しかし図5に示 すNJP誌例を見る限り，掲載料を上げたからといつ て論文投稿がなくなることはなく，見方を変えれば 学術誌としての価值に支持を得られれば, 有料・無 料関係なく出版は成り立つのだということを示して いると言える。

\section{3 オープンアクセスジャーナルの特徵}

言うまでもなく購読者（購読機関）を持たないと いうことは, 読者は多様な方法で論文を発見して見 にくるし，読者数や読者の属性の予測もつきにくい ことを意味する。どこから論文閲覧に至ったかと いう経路別閲覧数（referrals）を2誌についてみると 表1のようになる。STAM誌は月平均約12,000, NJP 


\section{Science and Technology of Advanced Materials}

March 2008 - May 2009

Top 20 Web Referrals

\begin{tabular}{|l|c|}
\cline { 2 - 2 } \multicolumn{1}{c|}{} & Total \\
\hline Total & 186,325 \\
\hline IOP Total & 96,872 \\
Google Total & 71,784 \\
en.wikipedia.org & 6,268 \\
Yahoo Total & 2,213 \\
www.diana-teknologia.com [xerka@diana-tek.com] & 1,416 \\
apps.isiknowledge.com & 1,315 \\
www.sciencedirect.com & 1,237 \\
www.scirus.com & 1,224 \\
www.doaj.org & 994 \\
www.pdf-search-engine.com & 568 \\
www.scopus.com & 448 \\
adsabs.harvard.edu & 357 \\
e-materials Total & 267 \\
toolserver.org & 265 \\
NIMS Total & 258 \\
prola.aps.org & 220 \\
www.engineeringvillage2.org & 193 \\
ru.wikipedia.org & 163 \\
ucelinks.cdlib.org:8888 & 142 \\
www.answers.com & 121 \\
\hline
\end{tabular}

表2 STAM, NJP誌のWebページ別アクセス数（COUNTER準拠）

\section{Science and Technology of Advanced Materials March 2008 - May 2009}

Accesses by Page Type
\begin{tabular}{|l|c|}
\hline \multicolumn{2}{|l|}{ Page Type } \\
\hline Abstract & Total \\
Full-Text Download & $\mathbf{8 0 , 9 2 9}$ \\
\hline Table of Contents & 30,749 \\
References & 35,788 \\
Volume & 3,305 \\
Journal Homepage & 3,018 \\
Citation & 2,041 \\
Sview & 1,560 \\
Issue & 1,318 \\
Postto & 390 \\
Recommend & 222 \\
Related Articles & 194 \\
Select & 76 \\
Unknown & 42 \\
Dataprot & 24 \\
Journal Editorial & 23 \\
Options & 20 \\
Search & 10 \\
Terms & 5 \\
\hline Total & 4 \\
\hline
\end{tabular}

\section{New Journal of Physics} March 2008 - May 2009

\section{Accesses by Page Type}

\begin{tabular}{|l|c|}
\hline Page Type & Total \\
\hline Abstract & $1,197,903$ \\
Full-Text Download & 852,502 \\
\hline Reference & 517,581 \\
Journal Homepage & 491,618 \\
Select & 233,020 \\
Multimedia & 213,726 \\
Table of Contents & 193,201 \\
Help & 164,450 \\
Table of Content Topic & 108,057 \\
Volume & 51,230 \\
Citation & 47,835 \\
Search & 22,634 \\
Postto & 22,314 \\
Sview & 21,755 \\
Recommend & 13,089 \\
Options & 7,899 \\
News & 7,840 \\
Contact & 6,560 \\
Referees & 6,234 \\
Subs & 3,818 \\
Issue & 1,746 \\
Unknown & 1,217 \\
Dataprot & 987 \\
Librarians & 676 \\
Related Articles & 494 \\
Feedback & 271 \\
Journal Editorial & 184 \\
Enquiries & 178 \\
Terms & 135 \\
Accolaim & 99 \\
Fcab & 39 \\
Samplecopy & 27 \\
Submit & 15 \\
Search_History & 3 \\
Orderform & 1 \\
\hline Total & $\mathbf{4 , 1 8 9 , 3 3 8}$ \\
\hline
\end{tabular}

\section{New Journal of Physics}

March 2008 - May 2009

\section{Top 20 Web Referrals}

\begin{tabular}{|l|c|}
\cline { 2 - 2 } \multicolumn{1}{c|}{} & Total \\
\hline Total & $1,713,260$ \\
\hline IOP Total & $1,219,833$ \\
Google Total & 362,857 \\
www.njp.org & 30,917 \\
Yahoo Total & 24,216 \\
scitation.aip.org & 10,574 \\
en.wikipedia.org & 8,226 \\
apps.isiknowledge.com & 7,759 \\
www.stumbleupon.com & 7,380 \\
prola.aps.org & 5,735 \\
www.techno-science.net & 5,461 \\
www.sciencedaily.com & 5,428 \\
physicsworld.com & 4,085 \\
techon.nikkeibp.co.jp & 3,597 \\
adsabs.harvard.edu & 3,503 \\
lhc.web.cern.ch & 3,433 \\
www.physorg.com & 2,401 \\
Elektronische Zeitschriftenbibliothek Total & 2,053 \\
news.bbc.co.uk & 2,022 \\
sciencenow.sciencemag.org & 1,958 \\
search.live.com & 1,822 \\
\hline
\end{tabular}

誌は11万のアクセスがあり，STAM誌はNIMSが読者 支持機関であることの他に，Wikipediaや材料ポータ ル (e-materials.net) も有力なゲートウエイになって いることが読み取れる。またSTAM，NJP両誌共に (1)GoogleやYahooなどの汎用検索エンジンが重要な ゲートウエイになっている, (2)物理・材料系主要誌 を被引用元としてたどって見にきていることなどが 特徵的である。見方を変えれば論文が汎用検索の結 果として，あるいは引用論文として発見され読まれ ていることである。また表2から，STAM誌の場合， 引用文献 (citation) 也関連論文 (related articles) を 重要なゲートウエイとして強化し, マルチメディア (multimedia) などを新たな集客ゲートウエイとして 開拓するということが考えられる。また日本の学 術誌として，和訳要旨をつけることで日本人サポー ターを増やす策も検討している。

不特定多数を読者対象とする場合，アクセスログ が唯一定量的に測定分析できる情報であり，そこか らオープンアクセスジャーナルとしての強弱の特徴 を見い出し, 研究者の日常的な論文発見経路に必ず 必読論文として登場するように，オンラインジャー 
ナルの仕組みを発展させることが今後とも強化した い点である。

またオンラインジャーナルのどこに見にきているかと いうことも重要である。例えばSTAM誌とNJP誌におけ る論文の引用リスト (references) が本文に次いで最も 多く見られるページであることや，引用文献 (citation) すなわちこの論文を引用している論文リストも，論文連 鎖という点で論文到達への重要な経路であることがわ かる。

\section{4. 学術誌への公平なアクセスを目指した 挑戦}

公平なアクセスを妨げる要因には，以下の3点が 考えられる。

(1)機関ごとの図書購入予算規模や機関属性の違いに よって，A機関が読めるのにB機関が読めないと いう格差（研究環境における視点）。

(2)図書館予算において高額な海外誌占有率が高く, 相対的に購読優先度が低くなりがちな日本の学術 誌が売れにくいというジャーナル間の格差（出版 者の視点)。

(3)国策として学術誌を収集し, 自国の研究環境亡し て学術誌資源の確保を整備しているかどうかとい う，国レベルでの格差（国レベルの視点）。

議論する主体と目的によって論点も異なるだろ う。格差をできるだけ少なくしてアクセスを実現す るため, 本稿の主眼点は冒頭に述べたように, 先端 研究に有用な学術情報の研究者間共有を支援するた めのオープンアクセスジャーナル化であり，セルフ アーカイビングの動きにも応える著者自身による著 作権活用のすすめでもある。

図書館購読型からオープンアクセスジャーナル化 への動きは, もともと1980年代から加速した学術 誌の価格高騰化に起因するものの，現在では論文の 出版そのものを，出版社を通さず，研究者たちの手 に戻そうという動きへと進展している10), 注10), 注11)。
投稿原稿が査読・編集工程を経て，一様な体裁に整 えられ, 便利なオンライン機能（論文内相互リンク， 図表のカラーやマルチメデイア対応，参考資料の添 付, 横断検索やセマンティック検索, 類似論文の出 版お知らせメール機能等々) をつけてインターネッ トで読める状態にするまでの工程は, 実費べース で平均的におよそ15,000円／頁前後の費用がかかる が注12)，この費用を著者もしくは所属する機関が負 担できれば，そもそもにして研究成果を多くの読者 に配信したいという要望は満たされることになる。 これを一つのビジネスモデル化した例として, 先に 紹介した物理分野のNJP誌のほか, 生物·医学系分 野ではBioMedCentralやPLoSという先行例もある。近 年ではオープンアクセス出版のコンサルティング 企業としてCo-Action Publishing社 16) という企業がス ウェーデンで登場した。商業出版社から独立して起 業し，学協会など顧客の注文に応じてオープンアク セス方法を提案, 実現するらしい。オープンアクセ ス誌の刊行そのものを受けるほか, 購読契約雑誌か らオープンアクセス誌への移行, 雑誌の編集·管理, 戦略·実務に関するコンサルティングを行うという。

他方で，オープンアクセスジャーナル化が “学術 誌への公平なアクセス”へ向けた唯一の取り組みで はないことは本誌の読者は熟知していると思う。例 えば出版費用を読者が負担するモデルとして, 学術 誌を年間購読するのではなく必要な論文を購入する 従量制包括契約（論文単体売り・料金は一括払いの 契約モデルなど）がある17), 注13)。今のところ日本で 実践した例はないものの研究現場に即した考え方と して，Web社会における多様化の中で実現を望みた い挑戦である。

\section{5. 日本人が求める学術誌の姿}

日本人はどのような学術誌を求めているのであろ うか。例えばインパクトファクターから見える日本 学術誌は，いずれもそれぞれの分野における世界順 
位をみても健闘している。それぞれの学術誌を支え るコミュニティーの支援が数字に表れていると言え るであろう。他方, 日本学術誌への不足感としてよ く議論の場であげられることは；

·研究者視点

自分の発表論文を多くの人に読んでもらう媒体と して, 日本学術誌は認知度が低い 読まれにくい ↔引用に結びつきにくい。

·図書館視点

予算減（購読中止）の取捨選択の中で，日本学術 誌の優先度 (購読希望度) は海外誌より低い $\rightarrow$ 中 止対象となりやすい。

·出版社視点

日本学術誌はノーベル賞受賞論文も輩出するなど 戦前からの出版史は古く, ネット時代における公 平査読・迅速出版・電子化配信（インフラ）も国 際基準にほぼ達しているが，論文流通力（読まれ る・買われる) で苦戦, マーケット戦略において 弱い。

·国・政策視点

日本学術誌全体のスケール，メディアとしての発 信力が見えにくく，欧米雑誌に比べて相対的にイ ンパクトファクターが低く, 日本の研究投資効果 としての成果が定量的に見えにくい。

·世界視点

“日本の”という国の区別でジャーナルを見ては いない。

といった点である。これらはオープンアクセス ジャーナル化したら解決できるだろうか？ 購読料 を下げたら解決するとも思えない。むしろ発行母体 である学会や出版団体において, 目指す学術誌の具 体的な姿と，それを評価する指標を設定すべきでは ないかと考える。

\section{STAM誌が目指す姿}

世界で理工系分野に属する学術誌はおよそ7,200 誌とされる。学術誌の数は研究生活において目を通 せる数をはるかに上回って飽和している。研究成果 として発表した論文が誰かの目にふれる確率, ひい ては引用される確率は, いかに焦点の合った読者に 配信できるかにもかかっている。このような論文飽 和の時代にあって, STAM誌は, 見えにくくなりが ちな材料研究の動向を時折に俯瞰し, レビュ一論文 として編集し, 材料分野や境界領域の研究者に確実 に届ける品質保証のメディアとしての学術誌を目指し たいと考えている。

\section{7. 謝辞}

本稿に含まれる考察にあたっては, 学会発行の学 術誌のあり方に真摰に取り組んでいる永井裕子氏 (日本動物学会事務局長), 林和弘氏（日本化学会学 術情報部課長), 研究者視点で物事の多面性に光を あてる轟眞市氏 (物質・材料研究機構光材料セン夕一 主幹研究員), 植田憲一氏(電気通信大学レーザー 新世代研究センター長・教授）との日頃からの率直 な議論に助けられたところが大きく，この場で謝意 を申し上げる。オンラインジャーナルのアクセス分 析については英国物理学会出版局のThomas Miller氏, Tim Smith氏の助力を得た。最後に, STAM誌の質の 高い編集は材料科学分野において長い研究実績を持 つ田中高穂氏（物質 - 材料研究機構特別專門職）に よって実現しており, 本稿の校正にも惜しみない助 力をいただいたことに御礼申し上げる。 


\section{本文の注}

注1）トムソンサイエンテイフィック社「Journal Citation Report 1999年版」で材料科学分野に収録されて いる雑誌数を目安としている。

注2）例えば文部科学省研究環境基盤部会学術情報基盤作業部会では学術情報発信というくくりで日本の 学術誌問題を1)，JSTやNIはどでも多面的な視点と立場から議論されている。本誌でも2007年に問 題点の要旨が根岸氏によって紹介されており2)，その内容は現在にも共通する普遍的な学術誌問題 と言える。

注3）学術誌（ジャーナル）の所有権は，誌名を含み所有している組織（owner organization）を意味し， 論文の査読・編集といった論文の内容に関する決定権はジャーナル所有組織が持ち, 学術誌の内容 について責任を持つことが学術誌出版における一般的な理解である。紙出版時代は, 論文著作権は 著作者がもち，そこに含まれる公衆送信権や翻訳権などの一切の利用を出版団体に認める（あるい は履行する権利を委ねる）場合が多かった。現在多くのオンラインジャーナルでは，オープンアク セス化や出版委託先を変更する場面などで, 誰が何に対して権利を持つか（責任を持つか）という 点を明らかにする必要が生じている。例えば(1)オンラインジャーナルプラットフォーム (Webの仕 組みや表示についての) の著作権はそれを制作した組織が，(2)論文著作権はその権利の利用・管理 の委譲を受けた組織または著者自身が, (3)ジャーナル所有権は所有組織が持つなどで, 明確にする 必要性が生じている。

注4）Tenopir氏による研究者の論文利用パターンの調査研究3)は, その後も継続的に論文発表されてい る。http://web.utk.edu/ tenopir/, (accessed 2009-07-01).

注5）時実象一氏は「オープンアクセス運動の歴史と電子論文リポジトリ」4）の4章で，2005年当時なが ら今にも普遍的なオープンアクセス論議に参考になる4つのシナリオを提示している。

注6）例えば材料分野ではAZoM.com Pty. Ltd社が出版するオープンアクセスジャーナル “Journal of Materials Online”がある。2005年に創刊, 著名な日本人研究者を含む国際編集委員会があり, peerreview journal, no publication charges, totally free to accessとしている。使っているジャーナルシステム はOpen Access Rewards SystemでAZojomo（http://www.azom.com/azojomo.asp，参照2009-07-01）で 出版されている。学術誌というものを考えさせられる一例である。

注7） Nature誌はWeb上で研究者・図書館・出版者の公開討論を行う場をホステイングしている8)。

注8) Open Journals System (Public Knowledge Project) など。日本でも大阪市立大学のJournal of Informatics (http://ojs.info.gscc.osaka-cu.ac.jp/Jl/index.php, 参照2009-07-01) で運用事例がある。

注9) “Scientific publishing in transition: an overview of current developments”は実際に導入されている事例と ともに科学分野での出版システムおよびプラットフォーム移行についてのレビュー記事である ${ }^{11) 。 ~}$ また別の文献12)ではシステムの比較についても言及している。

注10) “Beyond Institutional Repositories”は研究者による提案で, 機関リポジトリを出版プラットフォーム として位置づける場合の考察が述べられている15)。

注11) 轟眞市「セルフアーカイビングのすすめ」(http://Www.geocities.jp/tokyo_1406/node5. htm|\#link:selfarchive，参照2009-07-01）は研究者自身によるセルフアーカイブの実践例である。

注12) 論文出版費用のシミュレーションには, オープンアクセスジャーナルの著者負担料が最も実質 に近く適している。例えばBioMedCentralの “How much is BioMed Central charging?” , (http://www. biomedcentral.com/info/about/apcfaq\#howmuch, 参照2009-06-30).

注13) 論文単体売り (pay-per-view) に関する調査報告が以下から出されている。The Charleston Report. “By the numbers" $-78 \% \cdots$ the percentage of scholarly publishers who offer individual articles for purchase. By John Cox, 2008 from Scholarly Publishing Practice, the 3rd survey. 
1）“研究環境基盤部会 学術情報基盤作業部会”。文部科学省. http://www.mext.go.jp/b_menu/shingi/ gijyutu/gijyutu4/002-1/index.html, (参照2009-07-01).

2）根岸正光. 『学術情報基盤の今後の在り方について』第3部「我が国の学術情報発信の今後の在り方に ついて」. 情報管理. 2007, vol. 49, no. 10, p. 591-594.

3) Tenopir, C.; Kiing, D.; Boyce, P.; Grayson, M.; Zahng, Y.; Ebuen, M. Patterns of Journal Use by Scientists through Three Evolutionary Phases. D-Lib Magazine. 2003, vol. 9, no. 5.

4）時実象一.オープンアクセス運動の歴史と電子論文リポジトリ. 情報の科学と技術. 2005, vol. 55, no. 10, p. 421-427. http://www.dab.hi-ho.ne.jp/cirrus/Ref/Fulltexts/JKG55-10.pdf, (参照2009-07-01).

5）太田暉人, 林和弘. イノベーション時代の学術情報流通システム. 情報管理. 2006, vol. 48, no. 11, p. $717-722$.

6）林和弘. 日本のオープンアクセス出版活動の動向解析. 情報管理. 2009, vol. 52, no. 4, p. 198-206.

7) SAGE Publications. Meeting the challenges: societies and scholarly communication: Results of a survey to understand the needs of scholarly societies in the 21st century. 2008, 21p.

8) "access to the literature: the debate continues". Nature web focus. http://www.nature.com/nature/focus/ accessdebate/, (accessed 2009-07-01).

9) Houghton, John; Jonge, Jos de; Oploo, Marcia van. Costs and Benefits of Research Communication: The Dutch Situation. SURF Foundation Publication, 2009, 43p. http://www.surffoundation.nl/SiteCollectionDocuments/ Benefits\%20of\%20Research\%20Communication\%20_April\%202009_\%20FINAL_logos2.pdf, (accessed 200907-01).

10) Aymar, Robert. Scholarly communication in High-Energy Physics: past, present and future innovations. CERN, 2008, 16p. http://doc.cern.ch//archive/electronic/other/generic/public/cer-000700329.pdf, (accessed 200907-01).

11) Ware, Mark. Scientific publishing in transition: an overview of current developments. Mark Ware Consulting Ltd., 2006, 30p.

12) Ware, Mark. Journal publishing systems: outsource or in-house?. Learned Publishing. 2007, vol. 20, no. 3, p. 177-181.

13) "The Transfer Code of Practice" . UKSG. http://www.uksg.org/Transfer/Code, (accessed 2009-07-01).

14) in cites. "New Journal of Physics". http://www.in-cites.com/journals/NewJofPhysics.html, (accessed 2009-0701).

15) Romary, Laurent; Armbruster, Chris. "Beyond Institutional Repositories". Social Science Research Network. 2009. http://papers.ssrn.com/sol3/papers.cfm?abstract_id=1425692, (accessed 2009-07-01).

16) Scott, Peter. "Co-Action Publishing”. Peter Scott's Library Blog. 2007-03-30. http://xrefer.blogspot. com/2007/03/co-action-publishing.html, (accessed 2009-07-01).

17) 太田暉人. 学術情報流通の格差をなくそう. 化学と工業. 2009, vol. 62, no. 4, p. 453-454. http://www. chemistry.or.jp/kaimu/ronsetsu/ronsetsu0904.pdf, (参照2009-07-01).

\section{Author Abstract}

Science and Technology of Advanced Materials (STAM), which is an international academic journal in materials 
science, celebrates its 10th anniversary in 2009. The journal was founded in 1999 by the members of materials science related academic societies, in response to the momentum toward the creation of an international, high-profile, professional journal in Japan, a country leading the research in materials science. Most Japanese academic journals are published by academic societies as part of their activities; members support the review and editing of the papers as their community activities, and these academic societies gain profit or improve their social profile through the journal publication. STAM stands in a unique position in that the entire process of publication and management is carried out, in practice, by the National Institute for Materials Science (NIMS), although STAM is a product of the cooperation between NIMS and several academic societies. NIMS not only carries out research studies but also foster information dissemination research their achievements as the only institute specializing in materials science in Japan. The publication of an academic journal is thus considered as a core infrastructure development of NIMS. The goals of STAM are to publish review papers on marked achievements and progress in research and to share them in a community of materials scientists using the NIMS network and collaborative institutions at home and abroad, under the enthusiastic leadership of the NIMS President. To this end, NIMS, despite its institutional nature, must maintain the editorial operation and stable publication of STAM. Through a stepwise improvement of its operation and editorial system, STAM evolved from a subscription-based journal to an institute-supported open-access journal in January 2008. This indicates a change in emphasis from quantity, i.e., the number of papers, to quality, as the journal aims to include only papers essential to materials researchers. STAM adopts the model of a journal led by a community of researchers, in which scientists can freely report and review their achievements (free to submit), read papers (free to read), and obtain the copyright themselves (author-friendly copyright). The perspective from the time of creation to the maturation of STAM is overviewed by comparing STAM with New Journal of Physics (published by Institute of Physics Publishing), the academic journal launched in England before STAM with the same principle and one of the successful open-access journal models.

\section{Key words}

science and technology, academic journals, researcher community, institute-supported open-access journal, author-funded open-access journal, Science and Technology of Advanced Materials, New Journal of Physics, IOP Publishing 